\title{
Alfred Döblin's literary cases about women and crime in Weimar Germany
}

\author{
Alison Lewis
}

After the First World War, European writers turned increasingly to consideration of social problems in the metropolis, and the impact of the war on sexual and mental health more broadly. In particular, the topics of violence against women, and women who commit violence, which many writers began to tackle in new ways, proved popular among readers in Weimar Germany, especially in the cities of Munich and Berlin. Stories about real cases were at once frightening and titillating - and for the first time such stories were readily available, through the diversification of literary markets, and the plethora of newspaper and print media that began to report on contemporary trials and curious cases. Middle-class and petit-bourgeois publics were keen to consume thrilling and shocking stories of crime and sexuality in newspapers and novels. They did so, and as a result these publics grew more literate and discerning, which in turn compelled writers to invent novel ways of presenting the strange but real cases. On the one hand, authors whose professional lives brought them into close contact with remarkable real-life cases (of either sexual deviance or criminality, or both), found themselves uniquely placed to cater for the appetites of these publics. Through writing and publishing case studies based on their first-hand experience, they were able to capitalise on their insider knowledge of crime and the criminal mind. These writers could easily obtain graphic source material about sensational cases through their professional associations, and provide additional expert commentary on well known cases. On the other hand, doctors and judges needed to find a point of difference between their kinds of writing about the criminal mind and underworld and writing by other sources, such as first-person accounts of crime authored by con men and criminals themselves. The experienced writer of literature with additional expertise in medicine or the law was undoubtedly better placed to interpret these real-life cases and to draw general conclusions from them. Yet he or she needed to find new ways to seize and hold a reader's attention. This was the conundrum 
that aspiring young German writer Alfred Döblin (1878-1957), a medical practitioner working in one of Germany's most seductive and dangerous metropolises, faced at the beginning of the Weimar Republic.

Born in the seaport city of Stettin in 1878, Döblin was a resident of Berlin who trained as a medical practitioner. He had harboured literary aspirations from an early age, but suppressed them in order to pursue a passion for medicine and the natural sciences. Many novelists of the day, such as Ernest Hemingway, began their career as newspaper reporters and strove to replicate the facticity of newspaper reporting in their literature. By contrast, while concurrently pursuing a career in medicine, Döblin indulged sporadically in writing until he first met with commercial success in 1929 through the publication of his novel Berlin Alexanderplatz. ${ }^{1}$ Hence, it was not to journalism and print media that he turned to articulate his views on crime and violence - although Döblin did borrow his plots from the daily press - nor to the many psychoanalytic or medical journals of the time, but to literature. ${ }^{2}$

Here it will be suggested that literature provided Döblin (and indeed others before him, such as Bertolt Brecht and Erich Wulffen) with a metaphorical laboratory to revel and experiment in. Döblin's literary laboratory was not sealed off from the outside world, like a rarefied scientific space, but was an open, public forum that came with an appreciative audience, and with its own enlightened, educated reading public. This public was sufficiently distinct from other competing publics represented by newspaper readers and the like, and to Döblin it must have seemed advantageous to write for a 'captive audience'. Specifically, the so-called objective, empirically based literature of New Objectivity (Neue Sachlichkeit) in Germany offered Döblin a welcome medium in which to explore shocking and risqué themes of the day.

Many of Döblin's contemporaries, such as Erich Kästner and Hans Fallada, sought inspiration in the plethora of dynamic new urban spaces and milieus opening up in the cities of Berlin or Munich - seedy bars, brothels and alluring cinemas. Others, like Döblin, looked further afield to underpin their irrepressible flights of creative fantasy about modern city life. Döblin valued empirical sources for his stories, but, in addition to realistic settings, he chose to draw on the empirical human or "life' sciences for guidance. After all, Berlin was, as Andreas Killen observes, the 'breeding ground' for nervous and mental illness, and for a new discourse about nervous exhaustion, or neurasthenia. ${ }^{3}$ With its modern medicine and unique social welfare system, Berlin provided those writers like Döblin who practised a profession such as medicine with ample material to mine. In Berlin Döblin could observe the 'hidden costs' of modern capitalism in the rise of sexually motivated crimes and modern pathologies, which were now manifesting not merely as middle-class problems but as mass social phenonema. ${ }^{4}$

French writers of the nineteenth century had already observed that the modern age urgently needed to anchor its literature in real life and to 
document modern maladies. The sickness of their era was hysteria and writers such as Gustave Flaubert plumbed this topic for a voracious readership. ${ }^{5}$ But by the early twentieth century, bourgeois forms of cultural expression needed to adapt in order to contend with newer maladies and social ills. As the privileged cultural form of the Bildungsbürgertum, literature faced challenges from many quarters, challenges that an empirical turn could not adequately address without a more radical reinvention of the parameters of literature itself. In the modern metropolis, the writers of belles-lettres found themselves faced not only with great complexity and interconnectivity of life forms, but with competing and multiplying forms of knowledge about these life forms, which must have daunted any attempt to make sense of the many innovations in science and the arts.

In style and scope, Döblin's works have most often been compared to the high modernism of James Joyce and the American John Dos Passos. ${ }^{6}$ A writer of remarkable diversity and inventiveness, Döblin wrote on an astonishing range of topics, including the Manchu dynasty in China, the Thirty Years' War, modern urban life in Berlin, the 1918 November Revolution and European colonialism. He penned mostly novels as well as a few dramas, radio plays and dozens of essays on politics, religion and art. Although usually grouped under the banner of modernism, his works in fact span a number of quite heterogeneous genres, from historical fiction, science fiction, travel writing to crime fiction. While such breadth is possibly less surprising when one considers that Döblin witnessed some of the most turbulent decades of twentieth-century European history, the scope of his literary output, which now fills thirty volumes of "selected works', is by all standards impressive. He lived through the last years of the Wilhelminian era, two world wars, the Weimar Republic, National Socialism, exile in France and the USA, as well as the post-war Federal Republic of Germany.

It remains something of a mystery, therefore, that Döblin, although critically acclaimed as a writer of international stature, never achieved the popularity of other writers in the modernist canon, most of whom who were just as difficult and complex. ${ }^{7}$ In the Weimar Republic, Döblin was certainly a prominent figure through his short stories, his journalistic writings and his many novels - in 1925 Thomas Mann already described him as 'one of our foremost novelists'. Actually, few of his works were commercial successes until Berlin Alexanderplatz in 1929. Focused on a factory owner who loses a battle with his competitor, Döblin's second novel, Wadzeks Kampf mit der Dampfmaschine (Wadzek's Battle with the Steam Turbine), from 1918, was labelled 'cubist' and deemed a critical failure. ${ }^{9}$ Döblin was thought to redeem himself with his next novel, Wallenstein, a grand anti-war epic in two volumes, which went into a second print run. ${ }^{10}$

To be sure, Döblin was fortunate to have secured the support of an influential publisher in Samuel Fischer, who published his first work, in 1916 - about the Wu-wei resistance movement, Die drei Sprünge des 
Wang-Lun (The Three Leaps of Wang-Lun) - and subsequent novels until 1933. Döblin was in good company, since S. Fischer was also the publishing house of Germany's two other great writers of the era, Gerhart Hauptmann and Thomas Mann. But unlike Hauptmann, who had been awarded the Nobel Prize in Literature in 1912, and Mann, who was its recipient in 1929, Döblin's fame was largely limited to Germany. Throughout his career he lived very much in the shadow of his two literary forebears. When he found himself struggling to pay the rent in exile in Los Angeles as the Manns were preparing to build a palatial residence on the Riviera, he was reminded once again that he was, by comparison with Mann, only a middling writer. ${ }^{11}$

\section{Alfred Döblin, realism, naturalism and modernism}

Döblin's strongest literary influences were undoubtedly the great French realists of the nineteenth century, and the Berlin naturalists Hauptmann and Wedekind. And yet, in the 1930s, when Döblin was admitted into the canon of world literature, taking his place alongside Joyce and Dos Passos, it was not as a realist or naturalist but as a moderniser and modernist. ${ }^{12}$ Hence in German literary circles Döblin is rarely compared to his French literary forebears Gustave Flaubert, Honoré de Balzac and Émile Zola. This is curious, all the more so since Döblin proclaimed once in 1924 that the modern 'European-American world' was on the cusp of a naturalist age. ${ }^{13}$

Among French literary historians, German naturalism is often regarded as an imitation of French naturalism, which was superseded by symbolism and a new 'nervous romanticism'. In a recent revision of this idea, Stéphane Michaud has argued in favour of seeing classical works of German modernism by Musil and Döblin as the legitimate heirs to French naturalism. ${ }^{14}$ Alternatively, we could view expressionism, the successor to naturalism, as does Richard Heinrich, as a "naturalism of nerves'. ${ }^{15}$ Richard Daniel Lehan goes further, proposing that the literary modes of naturalism and realism were the crucial "vortex through which the novel passed' across Europe and the Americas for 100 years. Both naturalism and realism represent a "powerful way of seeing the physical world' that responded to large-scale social changes. ${ }^{16}$ Naturalism, for instance, can be considered a response to Darwinian theories of heredity and the environment 'that would ground the literary work in a factual and scientific context' ${ }^{17}$ Indeed, in Germany naturalism was far from dead at the turn of the century; it was being reinvented through the discipline of psychology. Naturalism's focus on heredity and degeneration was being replaced by an intense interest in human desire and the social determinants of human actions. ${ }^{18}$ Döblin's work demonstrates that naturalism found a new expedient ally in the medical, legal and psychoanalytic case history - that most empirical of new-found genres - thus prolonging the 
life of the naturalist spirit in global literature well beyond its heyday in the Second French Empire.

The diversity of Döblin's output has posed a challenge to scholarship. His oeuvre is most commonly linked to Brecht's innovations in epic theatre, especially since several of his major novels present epic treatments of grand historical themes. A feature of his approach to historical topics is, like Brecht's, his sympathy with the powerless masses of history. ${ }^{19}$ Closely related to this is another of his major concerns, namely with the harsh realities of modern urban life as experienced through various low-life or lower-class characters - criminals, prostitutes and working-class figures. But unlike Brecht, Döblin chose the medium of the novel to develop these themes rather than drama, and in doing so was possibly overshadowed by other great masters of the modern novel of the time in Thomas Mann and Robert Musil.

Berlin Alexanderplatz, written in the middle of his career, appears to stand across both strands of his writing: it manages to bring Döblin's fascination with the anonymous masses in history together with his keen interest in exploring individual psychology. Although its title suggests an epic treatment of a contemporary theme, the novel focuses on the fortunes of a recently released criminal, Franz Biberkopf, and is set on the fringes of the underworld of Berlin's teeming metropolis of the 1920s, with which Döblin was only too familiar from working with social welfare patients. Döblin develops a distinctive aesthetics of empathy for the "small man' in this work, which was to augur well for the novel's positive critical reception at the time and in later years. A pivotal stage in the development of the writer's avowed sympathies for the lower middle classes - which he shared with contemporaries like Kästner and Brecht but not with Musil or Mann - is a far less well known work, from 1924, Die beiden Freundinnen und ihr Giftmord (Two Girlfriends Commit Murder by Poison). ${ }^{20}$ This earlier work, so modest that it is often omitted from surveys of Döblin's oeuvre, is a case study that combines medical and legal traditions of case writing. It is this work, it will be argued, that plays a crucial role in the development of Döblin's specific brand of literary modernism.

These two literary works, which are both indebted to the case study genre, stand in a complex dialogic relationship to the newer styles of modernism and the older modes of naturalism and realism. In many ways, Döblin's works from this period of transition deserve Heinrich's epithet of a sort of 'naturalism of the nerves'. Döblin is often thought to belong to the camp of left-leaning modernist writers, such as Brecht, who responded to the crisis of individualism by advocating a revival of epic traditions in prose and drama. ${ }^{21}$ Scholarship has tended to stress Döblin's break with nineteenth-century realism and present his later works as a modernist breakthrough to a new anti-realist style. These classifications capture part of the story of Döblin's massive oeuvre; however, they fail to account adequately for the innovations Döblin made in documentary realism, or, more accurately, in criminal or medical realism. 
The case study genre can be shown leading the charge in innovating around the conventions associated with realism and naturalism. Rather than abandoning the realist traditions of the nineteenth century, through his case studies of ordinary working-class men and women situated on the fringes of respectable society (and with one foot in the criminal underworld), Döblin sharpens the tools in the traditional realist tool box. He does so by incorporating into his largely realist handiwork new medical, sexological means, as well as psychoanalytic instruments and knowledge. He also modernises the literary tools in the naturalist kit, applying the insights of the medically trained observer of sexual pathologies to real-life murder cases.

It was arguably the case study's emphasis on the individual, and his or her inner life driving social behaviour, especially its extremes such as murder and violence, that was to exert a decisive influence on Döblin's literary production. Moreover, the traditions of medical and criminological case writing were to inform Döblin's approach to literature at a crucial time in his development as a writer, eventually pushing him further in the direction of a forensic type of socially engaged modernism that is epitomised in Berlin Alexanderplatz. In Döblin's early historical epics, his focus was more on crowd psychology and behaviour than on the individual. ${ }^{22}$ In his futurist work from 1924, Berge, Giganten und Meere (Mountains, Seas and Giants), we can already see the beginnings of a more pronounced shift towards the individual. More so than this novel, however, it is a much shorter one that seems to hold the key to his aesthetic breakthrough, his true crime novel and medical case study of heterosexual and homosexual relationships, Die beiden Freundinnen und ihr Giftmord. A direct line can be traced from this work to Döblin's masterpiece of modernism in Berlin Alexanderplatz. Reading Döblin through the prism of the genre of the case study thus makes possible a more nuanced interpretation of his relationship to the two major literary modes of the time, realism and modernism. In addition, it facilitates revision of prevailing conceptions of the relationship between progressive politics and modernism. It can be shown that Döblin's experiments with the case study genre were unthinkable without his expert training in and first-hand knowledge of medicine.

With his mother, Sophie, and four siblings, Döblin had moved to Berlin in 1888, after his womanising and occasionally violent father, Max Döblin, had abandoned the family. As the second youngest sibling, Alfred Döblin was the only member of his immediate family to complete secondary school and enter university; like other writers of his time, such as Gottfried Benn and Arthur Schnitzler, Döblin undertook medical training. From an early age, he harboured literary aspirations while continuing to further his medical training and to establish his career as a medical practitioner and later as a psychiatrist. Döblin's first tentative attempts at writing literature began around 1900, when he was student of medicine in Berlin and Freiburg. His first two novels were written during this time, the second one finding a publisher only much later, in 
1919, when it was published under the title Der schwarze Vorhang (The Black Curtain). After completing his medical training, Döblin worked in various psychiatric clinics, spending a year in Regensburg and two years in Berlin-Buch, and gained further experience in Berlin hospitals, such as the Charité and the municipal Hospital Am Urban, where he met his future wife.

Döblin's friendship with editor, art critic and fellow Jewish writer Herwarth Walden dates from the time of his undergraduate medical studies. When Walden launched the Der Sturm (The Attack) in 1910, first a monthly periodical and later a gallery that served as a launching pad for expressionism, fauvism, cubism and the futurists, Döblin was one of its ardent supporters. Döblin had yet to publish a full-length novel when the First World War intervened and he was enlisted as a military doctor. In 1916 his first novel, Die drei Sprünge des Wang-Lun, appeared while Döblin was still stationed in Saargemünd in Alsace-Lorraine, France. Hailed as a breakthrough in the novel format, the work was a critical success and was even translated into French. However, as he remarked, in the early years there was little or no prospect of making a living from his literature.

Döblin does not appear to have regarded his medical and neurological training as anything more than a means to secure a living, and one independent from his hobby of writing literature. This is not to say that Döblin was not passionate about his medical work and research. He confessed, when reflecting on his life: 'medicine and science had an extraordinary hold on me'. ${ }^{23}$ In one autobiographical sketch, he describes spending years of his life, presumably between 1905 and 1911, 'wandering' around mental asylums, evading 'the struggle for so-called existence'. ${ }^{24}$ He felt strangely comfortable in the company of the mentally ill, he recalls, and alongside plants, animals and stones claims he tolerated only two types of humans: children and the mad. ${ }^{25}$

Döblin wrote his dissertation on alcohol-induced memory disorders under psychiatrist Alfred Erich Hoche in the years prior to the outbreak of the war. Döblin's lifelong mission to illuminate the causes of mental illness, which was later to drive his forays into literature, stems from his time conducting medical research: "the darkness that surrounded these sick people was what I wanted to help to illuminate' ${ }^{26}$ According to Döblin, his pre-war years spent in psychiatric clinics eventually led him to turn away from conventional psychiatry and to seek answers in the field of internal medicine. Through the work of Berlin's Institut für Sexualwissenschaft (Institute for Sexual Science) he inevitably became familiar with the latest theories on the 'inner secretions', or hormones. In his words, "you had to get inside the physiological, not inside brains, but maybe inside the glands, the metabolism' ${ }^{27}$

After Vienna and Zurich, Berlin was rapidly becoming the third major centre for psychoanalysis. ${ }^{28}$ Working in Berlin's large clinics brought Döblin into direct contact with many of the city's sexologists and psychoanalysts, who, under Karl Abraham, were to form the Berlin 
Psychoanalytic Institute in $1923 .{ }^{29}$ Where Döblin writes that Sigmund Freud's theories were no revelation to him - 'Freud was not a revelation to me personally' - this indifference must be taken with a healthy grain of salt. No doubt representing an underestimation of Freud's impact on himself, Döblin's claim possibly says more about Freud's pre-eminence in the field of psychoanalysis at the time. ${ }^{30}$ Psychoanalytic theories that were being formulated and tested in Berlin's hospitals and talked about in the newspapers were even dismissed by some as a 'craze'. ${ }^{31}$

By his own admission, Döblin was anything but indifferent to this craze of psychoanalysis: in 1928 he describes himself possessing a 'great sensitive receptivity, an exceptional capacity for analytical insight namely in the direction of the psychic-unconscious'. When professing in the same sketch to have been more influenced by physiology and neurology than by psychoanalysis, he merely seems to be indicating his preference for physical, somatic and neurological explanatory models of mental illness over purely psychological ones. Like most traditionally trained psychiatrists of the time, he had been schooled in the neurological and physiological determinants of mental illness, but in the post-war years he had increasingly engaged with a whole range of newer psychoanalytic ideas.

Döblin first became interested in psychoanalysis around the time he started working as a doctor in his own practice for social welfare cases. After the First World War and moving his practice to the city's eastside, to 340 Frankfurter Allee in Lichtenberg, he proceeded to train as an analyst in the Berlin Psychoanalytic Institute under the guidance of Ernst Simmel. He went on to join Abraham's reading group and encountered Erich Fromm, Wilhelm Reich and Melanie Klein. ${ }^{33}$ Döblin shared the social and political concerns of the Institute and became a member of the Verein Sozialistischer Ärzte (Association of Socialist Doctors), through which he came into contact with the work of Magnus Hirschfeld's Institut für Sexualwissenschaft.

His profound and, as suggested in his memoir, almost uncanny ability to plumb the depths of the psyche's unconscious proved a particular asset in Döblin's first explicit experiment with a medical topic, in Die beiden Freundinnen und ihr Giftmord. Because he was trained in many new empirical and clinical disciplines it seemed only natural to Döblin to try to tap into these insights, and to conjoin his two passions in life. His expert medical knowledge could form the basis for experimenting with new forms and styles of writing and allow him to indulge his latest interest.

Like Gottfried Benn, Döblin writes about the split in his life between literature and medicine. In the fashion of the period, he regarded both activities as evidence of the unifying entity of the individual genius, although Döblin never expressed the relationship in these terms. ${ }^{34}$ At the heart of Döblin's dualism is, of course, the myth of two cultures - that which C. P. Snow famously called the myth of two opposing cultural spheres. ${ }^{35}$ Despite his expertise in both medicine and the arts, Döblin 
always felt an uneasy tension between his work as a doctor and his endeavours as a writer. In two essays from 1927, 'Der Nervenarzt Döblin über den Dichter Döblin' ('The Nerve Doctor Döblin on the Writer Döblin') and 'Der Dichter Döblin über den Nervenarzt Döblin' ('The Writer Döblin on the Nerve Doctor Döblin'), he writes about the odd relationship between the two different aspects of his life. Not only does Döblin the doctor claim to barely 'know' Döblin the writer, he maintains that his literary works are "completely foreign to me and I am also completely indifferent to them' ${ }^{36}$ The doctor side of himself does not share the political views or the tastes in literature of his writer self. Döblin the writer, however, appears to have a far better relationship to his namesake in Döblin the doctor, and is at least curious to learn more about the life of a doctor, even to exploit it, if only to find source material for use in his writing. The split between Döblin's two passions in life is presented less in psychological than in sociological terms, and offers a commentary on the increasing specialisation of knowledge in the modern world. The writer is an individualist and a generalist, while the doctor is nothing out of the ordinary, a 'grey soldier in a quiet army', and a specialist. ${ }^{37}$ Yet Döblin the writer has an inferiority complex with regard to Döblin the doctor: 'I have defects, probably complexes, and the practised doctor probably sensed something' ${ }^{38}$ Despite the writer's greater fame, he feels defensive towards the doctor, as if intimidated by the knowing gaze of the psychiatrist, whereas the Döblin the doctor is unashamed of his ignorance of literature. From this exchange, it is not hard to adduce the crisis of dominant literary systems of knowledge. Discussing the viability of writing literature in an essay titled 'Ökonomisches aus der Literatur' ('Economic Observations from the Literary Sphere'), Döblin complains bitterly that, despite having published ten books, and selling 6,200 copies, in 1924 he had hardly earned more than 400 Reichsmark per month. He does admit, however, that his 'criminal case' of the two women who tried to poison their husbands sold 3,000 copies and, over the two years 1924 and 1925, earned him a total of 1,200 Reichsmarks. ${ }^{39}$

\section{Criminology and sexology in the literary case study}

Döblin wrote his novella Die beiden Freundinnen und ihr Giftmord for a new series of crime stories based on real criminal cases. His friend Rudolf Leonhard was keen to commission stories for a new publisher in Berlin, Die Schmiede, and called his series 'Außenseiter der Gesellschaft: Die Verbrechen der Gegenwart' ('Outsiders in Society: The Criminals of Today'). Döblin was to write the first work in what the editor hoped would become a lucrative new series. From Döblin's perspective Die beiden Freundinnen und ihr Giftmord combined a number of his professional and personal preoccupations, which he subjected to a new documentary style of treatment. He took a real criminal case as his material, borrowed 
extensively from journalistic and legal sources and, for embellishment, drew on his medical expertise and his personal experience. Döblin was interested in questions of sadomasochism, madness, sexually motivated violence and female sexuality, and the real criminal case involved all of these themes. From his autobiographical writings it is clear that Döblin also had personal experience of the toll that an abusive marriage could take on women. His sister Meta, who was tragically killed by shrapnel during the attempted November Revolution in Lichtenfelde in 1919 , had suffered terribly at the hands of her husband, who, according to Döblin, had married her only for her dowry. 'It was a terrible marriage', he writes. ${ }^{40}$

Döblin's novella centres on a famous legal case from 1923 concerning a woman who poisoned her husband out of love for another woman. Ella Klein and Margarete Nebbe were brought to trial in Berlin for attempting to murder their husbands by poisoning them with arsenic, and their trial touched a raw nerve with readers of the time. Like so many of his contemporaries, Döblin was fascinated and scandalised by the emergence of a new type of female criminal, and the spectre of the 'female poisoner', a phenomenon that Wulffen explored in his popular study Psychologie des Giftmords (1917). It reminded him of his sister and the abuse she had suffered, which might easily have escalated into a murder, had she not died during the November Revolution. Döblin recognised the potential of the criminal case for a wider readership, whose fears and anxieties about female sexuality had already been well nurtured by publications such as Richard von Krafft-Ebing's sexological study Psychopathia Sexualis (1886), Oskar Panizza's satires and Erich Wulffen's handbooks for lawyers and doctors Das Weib als Sexualverbrecherin (1923) and Psychologie des Verbrechers (1906, reissued 1908). The Klein-Nebbe case had been sensationalised in the print media in Berlin and the rest of Germany, and taken up by the international press as well. In addition to tackling the issue of the female criminal, it had the added intrigue of female homosexuality, or inversion, along with another modish topic of the day, the "perversion' of sadomasochism.

Despite having changed the names of the main characters - Ella Klein becomes Elli Link and Margarete Nebbe becomes Margarete (Grete) Bende - Döblin's novella is highly realistic and almost documentary in style. Readers contemporary with Döblin would have been familiar with the real court case from the extensive press coverage, and most would certainly have seen the novella as an exposition of the Klein-Nebbe murder case. Appearances are, however, deceptive, because in the novella the case is carefully crafted, or rather, woven from a bricolage of diverse source material, some medical and psychoanalytic, some journalistic.

On one level, the fictionalised case study composed by Döblin evokes the traditions of legal and medical-forensic case reporting that emerged over the course of the eighteenth century as part of a new 'forensic dispositif" made possible by new testing possibilities, the results of which could be 
deployed as evidence in trials. ${ }^{41}$ Increasingly throughout the nineteenth century, specialist medical knowledge became a topic of interest for a general reading public. In the eighteenth century, the Pitaval tradition of crime writing had already made sensational criminal court cases accessible to a lay reading public, and as middle-class publics expanded over the course of the nineteenth century so did the level of awareness of criminality and pathology, as well as competency in reading such cases. This was partly because in Germany after 1850 legal trials were opened to the public and newspapers were able to report cases of interest with greater fidelity. Moreover, literary writers were - with permission of the court - able to gain access to court materials and ground their own crime narratives in more reliable sources of empirical evidence, such as evidence presented at trials, as well as expert witness statements. ${ }^{42}$ With the advent of psychoanalysis, and of sexological theories about 'deviant' sexual behaviour in the twentieth century, the forensic dispositif came to focus on the criminal and her state of mind. By the time of the Klein-Nebbe trial, the courts deployed state-of-the-art medical evidence, often from competing areas within the same discipline, thus from all branches of forensic medicine, neurological psychiatry, sexual medicine and psychology. Of all the schools of psychiatry, however, the newer discipline of psychoanalysis was the least well represented in court cases. ${ }^{43}$ This lack of presence during trials can be explained by the fact that institutional acceptance of psychoanalysis developed slowly and with difficulty; this process was shaped by mutual disregard between the practitioners of the court and psychoanalysts, as explored in Chapter 4.

Döblin's literary case writing in Die beiden Freundinnen und ihr Giftmord is so faithful to the real case that it is hard to imagine he was not present during the five days of the Klein-Nebbe trial in March 1923. Yet all indications are that he was most likely not present, nor was he an expert witness during the trial, although he knew the doctors who had treated Willi Klein and he had spoken to Ella Klein and Nebbe. ${ }^{44}$ Döblin did, however, possess a copy of the Anklageschrift, the formal indictment which summarises the court proceedings, and was also familiar with the medical expert witness statements provided by sexologist and psychiatrist Magnus Hirschfeld, and two others, Otto Juliusberger and Friedrich Leppmann. Döblin's other main textual source is the comprehensive newspaper coverage of the trial over those five days; the reports were published in the morning and evening issues of virtually every national and regional newspaper in Germany.

Döblin's literary case study appears to be a good demonstration of the modernist aesthetics of New Objectivity, which aimed to move literature away from conventional psychology and closer to the human and empirical sciences, to be more documentary in style and to be a form of 'factual fantasy' ('Tatsachenphantasie'). ${ }^{45}$ Read as an elaboration of a criminal case, Die beiden Freundinnen und ihr Giftmord actually belongs to a much older tradition of crime writing. ${ }^{46}$ With its focus on the criminal, Döblin's 
story is typical of much of the crime writing that newly emerged from the second half of the nineteenth century onwards. ${ }^{47}$ In the vein of a criminal case study, the novella seeks to present a specific example ('Beispiel') of a more general human condition. Yet this instance is not offered as an exemplar, nor as an illustration of a norm or a point of law, nor even of a pathological condition in the usual way of criminal cases. ${ }^{48}$ Rather, it might be considered a concretisation of critic André Jolles's simple form of the Kasus, the universal form that discusses a criminal event in the context of a deviation from moral or legal norms. In Jolles's schema of 'simple' literary forms, the function of the Kasus is to pose questions and weigh up norms of social behaviour. ${ }^{49}$ Akin to the riddle, which is a question begging an answer, the Kasus poses a moral question via the crime, which often it can only partially answer - frequently by asking further questions. Döblin's story also appears to have much in common with legal and medical case writing, namely in the relationship between the specific instance and the general rule or hypothesis that the case seeks to extrapolate from the example. While the specific modality of this relationship can vary, the general can be inferred from the specific case in inductive forms, or prior to it in deductive forms, or simultaneously when

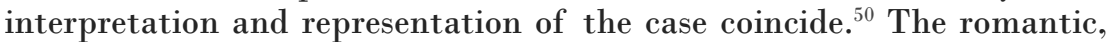
realist and modernist case of the nineteenth and twentieth centuries gave preference to the inductive method over the deductive. ${ }^{51}$

In writing Die beiden Freundinnen und ihr Giftmord Döblin relies heavily on the Anklageschrift and the newspaper reports from a host of Berlin newspapers. ${ }^{52}$ These sources all reported on the content of the 600 letters exchanged by Klein and Nebbe, and Döblin uses these letters as well. In a rather reductive fashion that was characteristic of newspaper writing of the time, the papers classified the women according to common gender stereotypes of the sadistic, hysterical, unscrupulous woman, and the cold, calculating and inhuman perpetrator. ${ }^{53}$ The Berliner Lokalanzeiger speaks of two "dehumanised women ... who wanted to divest themselves of their husbands, who had become a hindrance to them in their abnormal relationship to one another through the unscrupulous, cold and calculating usage of poison'. ${ }^{44}$ The demonisation of both women in the press is only slightly mitigated by witnesses who recounted Klein's abusive marriage and Willi Klein's alcoholism. This was a small detail that might have gone unnoticed by most readers, but it struck a chord with Döblin, and was to become the centre-piece of his literary treatment of the trial.

The main change that Döblin makes to extant accounts of the trial is to shift the focus from the inner, psychic realm of the criminal - the principal focus of the newspaper reports - to the space in-between, the intersubjective space between the two women and their conflicts. ${ }^{55}$ This innovation enables Döblin to break down the impression that there is a direct, causal link between crime and criminal agent, and perhaps also to deflect attention from the known fact that the actual murder was patently planned. Döblin's other main innovation is to introduce into his 
novella the concept of the unconscious. This concept had become one of his burning obsessions, and he presents it at the start of his own thinly fictionalised causal chain of events, thereby portraying his characters as figures in a complex game of psychical processes. For Die beiden Freundinnen und ihr Giftmord Döblin makes a second shift of emphasis in relation to the case: he intertwines psychological and social causes so as to make each one highly dependent on the other. This sets his account apart from those in the press. He thereby presents the crime as the result of an almost unfathomable confluence of social and psychological factors and conscious and unconscious motives.

Döblin's case writing is deeply experimental, and he seems to have been unsure of how to achieve the desired realistic effect and of how to acknowledge the many baffling aspects of the case. This uncertainty leads him to restate his argument several times within the one work, through the use of slightly different components, published in the original version of Die beiden Freundinnen und ihr Giftmord. The story of the murder is supplemented by non-literary and para-literary material, which have largely perplexed critics. At the end of the largely realistic narrative of the case appears a short epilogue with a commentary by the author. Following the epilogue are two one-page, illustrated analyses of the handwriting of each woman, 'Zu Ellis Handschrift' ('On Elli's Handwriting') and 'Zu Margaretes Handschrift' ('On Margarete's Handwriting'). As well, at the close of the volume of the first edition of 1924, and only in this edition, Döblin included an unusual psychiatric addendum, or afterthought to his narrative. Unbound from the text of the novella, and inserted in an envelope glued inside the back cover, the addendum presents a series of psychoanalytic diagrams, printed in colour on ten glossy pages DIN 476 in size. These diagrams represent a further illustration of the case, but in a specialist language and a non-discursive form. Given the title 'Räumliche Darstellung der Seelenveränderung' ('Spatial Representation of the Changes to the Soul'), the addendum comprises seventeen visualisations and two graphs.

Simply by virtue of these heterogeneous components of Die beiden Freundinnen und ihr Giftmord as first published, Döblin's literary case study is an anomaly. No doubt it was an indulgence on the part of the publisher, Die Schmiede, and his friend Rudolf Leonhard, who edited the series, to publish it in this form, which is conceivably why the diagrammatic addendum was not included in subsequent editions of the work. The end effect of the first edition is that Döblin rather overstates the intricacies of his interpretation of the Klein-Nebbe murder case; in other words, the impact of the additional, non-literary adjuncts is to overdetermine the myriad causal factors leading to the crime. In the literary narrative Döblin points to various causes of the murder, such as the lesbian relationship between Elli Link and Grete Bende, the violent and loveless marriages, the choice of rat poison, the psychology and pathology of the characters, each playing a role in the eventual crime 
of murder. Still, Döblin appears to think that his literary account of the case is insufficient, and with the addendum he decides to embellish it in formal, aesthetic terms. By embroidering the literary case study, adding extra-literary elements such as the epilogue and then the addendum, however, Döblin risks staging the case in several discrete acts. ${ }^{56}$ In each of these acts, he tries to elucidate the aetiology of the crime, with the help of distinct discursive formations.

In the literary sections Döblin provides his own aetiology of the case, stressing causal factors such as infantilism, homosexuality and the brutality of Elli Link's husband. ${ }^{57}$ In the first chapter of the narrative, the story of Elli Link and her abusive relationship with her husband is narrated; the second chapter tells of the lesbian relationship between Elli Link and Grete Bende, and their plot to kill their husbands. Finally, Döblin concludes with a summary of the findings of the trial and the verdict. Yet unlike the court reporters, Döblin is at pains to offer a sympathetic and impartial account, while censoring much of the original evidence produced at the trial. The court transcripts are full of explicit statements taken from the letters. By contrast, Döblin softens his account of Ella Klein/Elli Link's suffering, bringing his story back to this figure as a casualty of marital abuse. An important subtext to Döblin's version is that the husband of Ella Klein/Elli Link belongs to the large army of war-damaged and traumatised veterans from the First World War. He is one of the shell-shocked, unable to live up to ideals of masculinity, and doomed to repeat his wartime trauma in acts of senseless violence directed against his wife.

Döblin's account, however, never imparts the full details of the husband's past and his suffering during the war; instead, Döblin alludes to this in Willi Link's alcoholism and unmotivated violence. Rather, Elli Link is his main focus of attention, as she becomes the victim of a violence that is all-pervasive in society, and that emanates, as sexologists said it would, from damaged returned war veterans, who cannot distinguish between the war front and the home front. Elli Link is more victim than villain in Döblin's account, and the mitigating circumstances Döblin builds into his story point to an important function of his case study. The writer's aim is to humanise the criminal rather than diagnose her or him, and thus to elicit some sympathy and understanding for the plight of Elli Link.

Hence at the level of plot, the narrative is preoccupied with the psychosexual dynamics of Elli Link's marriage - described from the perspectives of both wife and husband - and the plan to murder Elli Link's husband, while the trial and the time in jail are given comparatively little coverage. The language used throughout is literary in the broadest sense, neither strictly medical nor psychoanalytic, although it is replete with allusions to common psychoanalytic terminology of the day. For instance, when referring to the work of the unconscious, Döblin uses the word unterirdisch (subterranean). While the behaviour and actions of his characters 
are clearly viewed through the lens of medical knowledge, Döblin's craft is purely literary.

Döblin's newest passion for psychoanalysis proves to have been the most significant additional influence on Die beiden Freundinnen und ihr Giftmord. Ernst Simmel, Döblin's mentor, had experimented in treating war trauma and neuroses - he had been posted in East Prussia during the war as a military doctor. Döblin would have been familiar with Simmel's publications on the topic. ${ }^{58}$ Through his other contacts with the Berlin Psychoanalytic Institute, Döblin was exposed to a wide range of psychoanalytic theories and case studies. The main traces of psychoanalysis in Die beiden Freundinnen und ihr Giftmord are evident in Döblin's handling of unconscious matter. This can be seen in sections of the novella itself, but also in the schematic addendum, the 'Räumliche Darstellung der Seelenveränderung'. In the literary case study, Döblin alludes in general terms to that which Döblin the doctor, following the lead of Freud, would probably call the unresolved Oedipal complexes of Elli Link and Grete Bende. $^{59}$

In Döblin's story, the 'light-hearted and funloving' Elli naively marries Willi Link because of the man's similarity to her father, and Döblin mentions that Elli's chosen husband even has the same profession as her father. ${ }^{60}$ But problems soon start in the marriage, stemming in part from what seems to be Elli's as yet unresolved Oedipal complex. Grete Bende, too, appears to have strong, unresolved Oedipal ties to one parent, her mother: 'Grete had remained unfree due to the close devotedness to her mother'. ${ }^{61}$ In keeping with the Oedipal theme, Döblin describes a key turning-point in the Links' marriage in pseudo-psychoanalytic terms as a 'subterranean disappointment' ('unterirdische Enttäuschung'). ${ }^{62}$ Döblin thus suggests early in his narrative that a 'normal' transference of Elli's desire from her father to the husband becomes impeded. Hence, Elli experiences a 'disappointment' and she regresses to an earlier, apparently pre-sexual stage of development.

Elli's disappointment with her husband, as one of the multiple factors behind the breakdown of the marriage, leads ultimately to the emergence of Elli's homosexuality. To focus on the psychoanalytic addendum at the end of Döblin's case writing is to find this reading reinforced but not enriched in a substantial way. In the addendum, homosexuality is likewise depicted as a complex. It first emerges in Grete Bende, in 'phase 10', and in 'phase 11' in Elli Link. Grete Bende is ascribed a 'normal sexuality' that is 'well developed' and her homosexuality comes to the fore only when she meets Elli Link. The same occurs with Elli Link, whose desire for Bende tapped into dormant tendencies that Döblin identifies in the narrative as 'an old mechanism that was in the past'. ${ }^{63}$ The addendum thus suggests that Elli Link's homosexuality is not necessarily congenital or innate, but a response to social or interpersonal circumstances. The emergence of homosexual desire is presented in psychological terms in relation to parental love, as with Freud's Oedipal complex. 


\section{Psychoanalysis and literature's answer to life science}

The psychiatric addendum included in the 1924 edition of Die beiden Freundinnen und ihr Giftmord offers a type of expert commentary on the Klein-Nebbe murder case, in which Döblin reframes the crime and its circumstances in the language of psychology and psychoanalysis. As an additional narrative, the diagrams help to sharpen Döblin's focus on the case, in that they foreground the psychic disposition of the three main characters in relation to one another over the course of a couple of years, taking up the themes of the homosexuality of the two women, all three main characters' sadomasochism and Willi Link's perversion. At the same time, with its specialist, psychiatric discourse, the addendum does little to illuminate the literary account, neither strengthening the coherence of the preceding narrative nor adding greater depth; also, it introduces no additional factors attenuating the crime that are not already apparent in the fictionalised version.

As argued, the addendum serves instead to overdetermine the evidence already in circulation about the Klein-Nebbe murder case. So why did Döblin include it? One answer is that in highlighting the psychological determinants of the case, say, over the social or physiological factors, the pseudo-medical addendum would seem to lend legitimacy to newly emerging psychoanalytic epistemologies about sexuality and perversion. It does so without substantially affecting the literary rendition of the case, which is a rendition capable of much finer analysis. With regard to the genre of the case study, Döblin's creation in the first edition of Die beiden Freundinnen und ihr Giftmord is nonetheless significant for what it conveys about the relationship between the literary laboratory and the case study in 1920s Germany. More specifically, Die beiden Freundinnen und ihr Giftmord demonstrates the specific contribution that literary cases can make.

By the time of Döblin's experiments with criminology, sexology and psychoanalysis in Die beiden Freundinnen und ihr Giftmord, literature had evolved as a medium of communication in unforeseen directions. The demands of realism, empiricism and now modernism all altered the way that writers strived to respond to modern life's many new challenges. Certainly, in Weimar Germany Döblin found a broad, heterogeneous public for his hybrid achievement in the novella. And yet, the experimental nature of Döblin's case writing suggests that while the reading public might have become more capable of embracing greater complexity in literary texts - medical, sexological, legal, psychoanalytic complexity literature struggled to cope with this complexity.

The remarkable epilogue to Die beiden Freundinnen und ihr Giftmord provides a number of clues as to why Döblin overburdened his literary case study. ${ }^{64}$ The work began as realistic, documentary-like reportage, but ended as a wild cacophony of discourses and diagrams that do not mesh or meld: 
When I cast my eye over the entire thing, it seems like it was in the story: 'and then the wind came and tore down the tree.' I don't know what type of wind it was and where it came from. The whole is a carpet which consists of many individual bits, of cloth, silk, metal pieces as well as lumps of clay. It is stitched together with straw, wire, yarn. In some places the parts are only loosely connected. Other fragments are connected by glue or glass. And yet it is all seamless and bears the mark of truth. And this is the way it happened: even the actors think so. But it could easily not have happened this way. ${ }^{65}$

In the metaphor of a carpet, woven out of cloth and silk but also metal and clay, Döblin has found a powerful image for his multidisciplinary creation. Unsurprisingly, he is not entirely convinced that the heterogeneity of methods used has created an integrated whole. That some sections of the carpet are woven out of glass, rope, straw and clay - that is, out of material that is normally extraneous to rug weaving - is an admission that he is not happy with the coherence of his work. On inspecting its odd structure, the image of a patchwork proves no exaggeration. Indeed, more than a carpet, the case could be seen to resemble a garment or a coat, even an overcoat; the body woven out of literary fabric, while the rest is made of other disciplinary material. This overcoat could be thought to have, for instance, graphological sleeves from the two analyses of the accused's handwriting included after the epilogue. The same woven overcoat has an added frame or fringe in the epilogue and, at the back, a secret gusset, tucked away out of sight, in the ten unbound leaves containing the psychoanalytic emplotment of the case.

The metaphor of a patchwork carpet or coat aptly captures Döblin's keen sense of the multiple causal factors at play in this intriguing case. Yet he is baffled and bewitched by its complexity. As the patchwork shows, this complexity is unwieldy and irreducible; the coherence of the case is not so much enhanced by the multiple perspectives as undermined by them. Döblin, it seems, balks at the disciplinary richness and determinism of the case - a response all the more perplexing given that he was an expert in most of the specialist discourses included in Die beiden Freundinnen und ihr Giftmord.

The contemporary crisis of literature, and the writer's own existential crisis, echo throughout Döblin's epilogue. As a commentary on literature, this aspect of Die beiden Freundinnen und ihr Giftmord underscores Döblin's pessimistic perceptions of the limitations of literary case writing. While purporting to offer a commentary on the verdict of the court case, the epilogue ends up negating the value of definitive diagnoses; that is, it undermines the epistemological basis of case writing. Paradoxically, the epilogue serves both to distinguish the difference that literature makes and to negate the ability of the literary case study to make definitive judgements about cases altogether.

The topography of the souls of the three main characters and the seventeen phases of the addendum can be called a curiosity. Undoubtedly 
it allowed Döblin to display his expert knowledge and his cultural capital - such as his familiarity with Freud's topographical model of the soul, Adler's physiological models and Jung's theories of complexes, as well as his vast knowledge of current psychological and psychoanalytic ideas. As such, the addendum stresses the helplessness of the modernist writer, who cannot turn back the clock to realist and naturalist times, but who cannot solve the challenge of modernity's epistemological complexity and diversity. This complexity of modern life - specifically modern sexual life and the depths of the modern psyche - presented the greatest challenge of all to writers of literature, and in particular to those clinging to New Objectivity. Döblin's compulsion to blur the boundaries between the literary and the psychoanalytic case study in the one publication, and to overburden his literary treatment with additions, points to a severe crisis in aesthetics, one mirrored in the real existential crisis of the 1920s writer, who cannot live solely from literature.

Of course, Döblin was not alone in grappling with the exigencies of modern life through literary forms that no longer seemed fit for purpose. His work therefore reflects much of the multidisciplinarity of the case genre of the period, and the openness of the literary case study to external influences at this historical juncture. Döblin must have been aware that his new type of forensic case study was not designed for the petit-bourgeois readers of 'penny dreadfuls'. He hints at this in the essay about the rift in his life between his literary interests and his professional activities. As a doctor he does not share his namesake's heightened imagination, and does not like to read the sort of literature written by Döblin the writer. He prefers to read factual literature - travelogues, for example. He also prefers books written in a less heavy style: 'it is too heavy for me, you cannot expect worn-out people to work their way through something like that voluntarily'. ${ }^{66}$

Die beiden Freundinnen und ihr Giftmord could be read as a realist case study written in a modernist age. It is a work symptomatic of the inter-war years in Europe, and particularly in Germany, which struggled to overcome the traumas of war neuroses and shell-shock, and found itself faced with a new war on the home front, in domestic violence. Here Döblin attempts to link cause and effect in new ways, to show the impact of war on peacetime - yet, ultimately, the experiment fails, because he locates not one cause or one effect, but multiple factors that all contributed to the violence of the murder. The sheer complexity of modern life in Weimar Germany, of men and women living in the shadow of war and violence, prompted Döblin to take the timeworn form of the case study and give it a twist so violent as to make it virtually unrecognisable. To be sure, he still places a criminal at the centre of his case history, but the female criminal is not presented as a specific instance of a general rule for disciplinary action or prevention. There is no clear moral to her acts or to Döblin's story, no point of law that he makes. Similarly, his findings in the addendum are less than equivocal. Homosexuality is not 
so much congenital as a response to parental love, and can sometimes be circumstantial. Finally, Döblin's insistence on enriching his account of the murder case with psychoanalysis is less than satisfying. While he claims to have jettisoned psychology entirely, this is not true. Psychoanalysis certainly informs his writing, but the full impact of ideas about the Oedipal complex, sadomasochism and perversions is really felt only in the diagrammatic addendum.

Instead, in the laboratory of literary culture, the exception or deviation from a norm or rule is normalised as a possible modality of the all-too-human. This laboratory functions best, however, when it remains an inexact science. As Bernhard J. Dotzler remarks, all literature transports knowledge but not all knowledge is science. ${ }^{67}$ Döblin possibly forgot that literature is not science. Hence the topographical diagrams of the addendum, which were never republished in subsequent editions of Die beiden Freundinnen und ihr Giftmord, seem out of place in a literary work. For writers and artists with a commitment to New Objectivity, the solution to the crisis of literature was to reground literary communication about sexuality and female criminals in the empirical life sciences, only to realise, perhaps too late, that literature had a much more sympathetic complement in psychoanalysis. And yet, as contended above, the mere addition of psychoanalytic models after the close of the narrative does not necessarily improve readers' understanding of sex crimes. The literary work does not gain from the authentication strategy of the addendum, although to Döblin the literary account must have seemed deficient enough to require further, expert padding. As a result, in this instance, the case study genre became so overdetermined by extra-literary discourses, so overwhelmed by disorder and sheer complexity, that it threatened to separate into its constituent parts altogether. This is indeed what Döblin's patchwork creation did over time, insofar as the hidden gusset of the coat disappeared from public view into the archive. Meanwhile, his literary case survived to the present day, in the public domain, to be republished as part of all subsequent editions of the work.

Döblin's first foray into literary case writing presents an extraordinary case of murder in order to show that extreme behaviours are possible and hence potentially part of the spectrum of the normal. While some kinds of naturalism in literature could be accused of 'inscrib[ing] new normative constraints', overall Döblin's first such treatment of the case study appears to have the opposite effect: by taking deviance as paradigmatic of the normal it disrupts the association of normal sexuality with heterosexuality, and brings the extraordinary or abnormal into the range of possible human behaviours. ${ }^{68}$

This can be seen from the narrative techniques that Döblin uses in Die beiden Freundinnen und ihr Giftmord. He combines the neutral focalisation of an objective or heterodiegetic narrator with rapid changes in perspective, switching frequently into free, indirect discourses to present his characters' inner states of mind. The effect is to provide insight into 
the motivations and psychic dispositions of all his protagonists, and to foster empathy, or at least insight. In addition, such close proximity to the thoughts and emotions of the criminal inevitably humanises her, and furthers a particular type of knowledge about crime. This is a type of knowledge that perhaps only literary genres can foster, though their unique capacity to present what Rita Felski has called a 'social phenomenology' ${ }^{69}$ The distinctiveness of the literary mode is manifest in Döblin's faithfulness to his sources; he quotes directly from the women's letters, while remaining careful to contextualise much of the evidence given at the trial, either through reference to Ella Klein's/Elli Link's terrible inner conflict and pangs of conscience, or through graphic descriptions of her husband's abuse. Döblin seems to have omitted most of the extremely revengeful and hateful parts of the letters, included in the newspapers and court transcripts. Very little of the women's direct coarse language is included in Döblin's story, except for one reference to the husband as a 'bastard'. ${ }^{70}$ Döblin's reference to the women's increasing desperation when the rat poison does not take effect is embedded in the broader context of Ella Klein's/Elli Link's husband's continued brutality. This helps to ensure that the reader regards her as the victim of an increasingly perverse, depraved and violent husband, a woman who is driven to murder as a last resort: "she was affected by her fate like her husband. Her life was in danger'. ${ }^{71}$

Döblin's humanisation of the accused women is assisted by his use of specialist discourse. By choosing not to characterise the women's homosexuality as a perversion, he points to an important function served by the literary case in his time - that of understanding and illuminating from a wide range of perspectives the complexity of female criminality, as distinct from classifying, diagnosing, pathologising or demonising the criminal. Apart from the expert diagrams of the addendum, Döblin uses empathy as his principal means. Empathy, argues Joe Bray, is 'central to developing an understanding of literariness and the value of literature' ${ }^{72}$ Accordingly, Döblin undermines the stereotype of the Giftmörderin by complicating the narrative with other circumstances, social, emotional, psychoanalytic, developmental and sexual causes, all of which might have contributed to the act of murder. The hybrid genre of the despecialised and fictionalised case study permits him to achieve all this in one work. The vast scope of this genre can encompass discourses from the empirical human sciences and psychoanalysis; having first distanced them from their conventional professional purpose, Döblin reintegrates them, in a dialectical move typical of the times. ${ }^{73}$ The specialist discourses are reframed in terms of literary communication, resynthesised and recoded according to binary categories characteristic of literary work: the categories of the possible and the probable. As the simple form that pits norm against norm - presenting human life as something to be valued and measured against a norm - the case study becomes the ideal method for questioning the certainties of specialist discourse and its truth claims. ${ }^{74}$ 
The case can thus pose a question without providing an answer, leaving it to the reader to weigh up evidence against other evidence. Döblin's case writing in Die beiden Freundinnen und ihr Giftmord emphasises the complexity of murder as the confluence of multiple factors, and hence refuses a monocausal explanation or a clear-cut attribution of guilt; his case delegates this task to the reader. In the laboratory of literature, the deviation is depathologised and reintegrated into the broad spectrum of normality, recoded as a possible modality of the human. The literary case thus manages to resist classifying the murderer as medical and legal discourses do. It defies the dominant forensic dispositif, and ultimately undermines epistemological certainty rather than contributing to it, thus disrupting the knowledge production of the specialist discourses it so deftly borrows from.

\section{Berlin Alexanderplatz: the case study of collective psychopathology}

The 'havoc that World War I continues to wreak' on the urban population and relations between the sexes are themes even more pronounced in Döblin's last novel from the 1920s, Berlin Alexanderplatz: Die Geschichte vom Franz Biberkopf (Alexanderplatz Berlin: The Story of Franz Biberkopf $).{ }^{75}$ He first began writing the work late in 1927, possibly inspired by Walter Ruttmann's famous documentary film of the same year, Berlin - die Symphonie einer Großstadt (Berlin: Symphony of a Great City). Berlin Alexanderplatz was first presented to the public in serialised form in the newspaper Frankfurter Zeitung in twenty-nine instalments, before being released as a book in October 1929 with a print run of 10,000 copies. ${ }^{76}$ It was heralded as the outstanding literary achievement of the year and new editions soon followed. By 1936 it had been translated into nine languages, including English (published in 1931 in New York and London). ${ }^{77}$

Franz Biberkopf, the novel's working-class hero, has served time in Tegel prison for murdering his girlfriend, Ida, and is released into the pulsing metropolis of Berlin at the end of the Weimar Republic and on the eve of the National Socialists' ascent to power. Although determined to lead a 'decent' life, Biberkopf soon falls into disreputable company and loses an arm when his new friend Reinhold thrusts him out of a getaway car. The last section of the novel sees him return to his old ways of living the life of a pimp and a petty criminal with the result that he is almost charged with murder once again when his girlfriend, the devoted Mieze, is murdered by Reinhold. Biberkopf is cleared of any suspicion but is physically and psychologically broken by the experience, falling into a catatonic stupor in Berlin-Buch. He recovers after a close encounter with death and is effectively resurrected as a new man, finally finding a respectable job as a porter in a factory. 
Biberkopf's story is told in part as a modern cautionary tale: above all, a tale of extreme, uncontrolled violence, of men pitted against men and, more worryingly, of men against women. As Veronika Fuechtner states: 'in Berlin Alexanderplatz, modern life is a war' ${ }^{78}$ While women in this novel are the victims of male violence, the sexes are, as in Die beiden Freundinnen und ihr Giftmord, very much at war. Maria Tatar observed that 'Biberkopf hardly ever makes a move that is not in some way coloured by his relationship with the opposite sex ... the women he encounters are habitually presented as the victims of rape or murder and are disempowered or effaced from the written page with a frequency that is nothing short of alarming' ${ }^{79}$

Berlin Alexanderplatz is regarded as Döblin's greatest contribution to a left-leaning modernism: he abandons many constraints of realism and achieves the much-sought-after synthesis of discourses and knowledge that was lacking in Die beiden Freundinnen und ihr Giftmord. The narrative is not strictly linear - instead, Döblin develops a polymodal and polyvocal form of narrative that is similar to but different from the interior monologue characteristic of modernist writers such as Joyce. As Walter Benjamin once remarked:

The stylistic principle governing [Döblin's] book is that of montage. Petty-bourgeois printed matter, scandalmongering, stories of accidents, the sensational incidents of 1928, folk songs, and advertisements rain down in this text.... Formally, above all the material of the montage is anything but arbitrary. Authentic montage is based on the document. In its fanatical struggle with the work of art, Dadaism used montage to turn daily life into its ally. ${ }^{80}$

The first reviews of the novel immediately compared it to Joyce's masterpiece Ulysses, which appeared in English in 1922 and in German translation in 1927. Döblin was quick, however, to deny any direct influence of Joyce, although the comparison no doubt contributed to the international success of the work. Rather than adapting Joyce's technique of stream of consciousness, Döblin's new approach, which he outlined in an essay written around the same time, 'Der Bau des epischen Werks' ('The Construction of the Epic Work'), was to explore the use of the epic mode in combination with even more extensive experimentation with techniques of montage. According to Döblin, the epic is founded on the form of the report, which the author can use for more than merely reporting facts: 'he uses it for his notorious non-facts', and for manipulating reality. ${ }^{81}$ The epic draws much of its veracity from the exemplary nature of its characters and action, from its 'powerful fundamental situations, primordial situations of human existence'. ${ }^{22}$ Like his contemporary Brecht, Döblin envisaged the epic as a new open form of narrative with no predetermined plot-line, giving the narrator maximum freedom either to intervene or to retreat from his subject matter. ${ }^{83}$ The openness of the form allowed him to break down the boundaries between myth and fact, between literary and scientific discourse, the collective and the individual. ${ }^{84}$ 
In the spirit of this new interest in modernising the epic tradition, Döblin superimposes on the story of Franz Biberkopf a dense layer of mythological, biblical, scientific and popular references, from statistics, descriptions of medical conditions and his own eyewitness reports from a local abattoir, to quotations from the Bible and the story of Job, street ballads, political songs and nursery rhymes. Through further refining the technique of the montage, which he appears to have taken from the new medium of the cinema, Döblin synthesises heterogeneous narrative matter from a wide range of information about the city itself, including short biographical vignettes about its other inhabitants. This time he does not stage his narrative repeatedly through the use of disparate discourses and sources, as seen in Die beiden Freundinnen und ihr Giftmord. Instead, he incorporates all his external source material and intertextual allusions directly into his text, often literally with scissors and glue, with inserts marked by letters or symbols or with Dadaistic collages. ${ }^{85}$

By the time Döblin wrote this masterpiece, his literary 'tapestry' was so rich in texture that critics have repeatedly been tempted to say the novel has not one protagonist but many; not the individual criminal but Berlin, the teeming, devouring metropolis, the Whore of Babylon herself. Indeed, the power of external stimuli from the vitalistic life-world of the city is so great that arguably it can no longer be contained by the genre of the individual case study. If Biberkopf's subjective experiences are to be understood as the collective experiences of a new, subjugated urban citizen - and if novelistic character is more an 'anthropomorphic device' than a believable construct with psychological interiority - then Döblin's reinvention of the case study in Berlin Alexanderplatz expands the case genre in radical ways, taking it into new territory for the modern novel. ${ }^{86}$

Döblin's novel has been read as both a 'city-epic' and a 'gruesome criminal ballad', which testifies to Döblin's ongoing fascination with the criminal underworld of Berlin. ${ }^{87}$ But it is an unconventional crime story, since it picks up the criminal's narrative after his release back into the community and, hence, it is no longer concerned with the threat of crime but with urban criminal life-worlds. The plot is only partially focused on criminal acts, and instead focuses on Biberkopf's rehabilitation and the multiple threats to his successful reintegration into society. Hence Döblin's narrative explodes the boundaries of the criminal case study, not only by virtue of the fact that he seems to regard his main character less and less as a recidivist criminal or a repeat offender and more and more as an everyman - as an individual with allegorical resonances.

Such a perspective on Biberkopf is underscored by Döblin's use throughout the novel of an ironic street-ballad narrator, the narrator of the murder ballad (or Moritat), who comments on, interprets and moralises about Biberkopf's fate. This explicit use of an authorial narrator contrasts with the virtual disappearance of the narrator in many of the montage or collage sections, which are stitched together without the aid of commentary. Indeed, the narrative voice is itself 'montage-like': it is 
'not a constant preterite presence with a firmly established vantage point, but a compound voice, a series of contrasting attitudes, a prismatically broken point of view in keeping with Döblin's injunction ... to be "decisively lyrical, dramatic, even reflective" ${ }^{88}$ With multiple masks and personas, including a new-found didacticism that helps him illuminate the case, Döblin's narrator is no longer the objective but the empathetic narrator of the case study, as in Die beiden Freundinnen und ihr Giftmord, who had struggled to diagnose or pinpoint the exact causes of the murder. Indeed, the voice of Döblin's narrator summarising the moral of the tale is not taken from the empirical, scientific world of the modern medical case study. Rather, it originates in the disparate sources of the chorus of Greek tragedy and the streets of Berlin:

We have come to the end of our story. It has proved a long one, but it had to unfold itself, on and on, till it reached its climax, that culminating point which at last illuminates the whole thing... It was a strange process of revelation. Franz Biberkopf did not walk the street like us. He rushed blindly down this dark street.... ${ }^{89}$

Döblin's many departures from the conventions of crime writing in recounting the story of Biberkopf's rise and fall manage to avoid the appeal to theories of racial 'degenerescence' and decline typical of naturalism. As Irene Gammel has observed: 'despite the growing rejection of the heredity-degenerescence model in the twentieth century, the plot of decline remains prominent in twentieth-century social realism'. ${ }^{90}$ Despite Biberkopf's best intentions at leading a life of respectability upon his release from jail, he cannot escape from the vicious circle of violence and crime in modern society. This is not because of any innate disposition or hereditary determinism (as associated with alcoholism, for example, in works by Zola and Hauptmann). Ultimately, Biberkopf falls prey to the violence that is endemic to the working-class and criminal milieu in which he moves in Berlin, unable to rise above those underworld circles of pimps and petty criminals or to gain a foothold outside their circles. As such, Biberkopf's fate testifies to the pervasive "paranoia of proletarianization' that Döblin no doubt himself felt and that affected all middle-class Germans in the midst of the 1929 global stock market crisis. ${ }^{91}$

Döblin's focus on criminality and violence surfaces again towards the conclusion of Berlin Alexanderplatz, where Biberkopf's sadistic friend Reinhold Hoffmann lures Mieze, Biberkopf's girlfriend, into a forest and murders her in cold blood. In this powerful scene, Döblin mobilises all the generative possibilities of montage into a highly dramatic finale, simultaneously staging a radically new modernist aesthetic that represents an important innovation in the literary treatment of violent crime. He combines rapid changes of perspective between Hoffmann and Mieze, male to female, villain and victim; he shifts from direct to indirect speech, from authorial commentary to biblical fragments from Ecclesiastes, from a language of emotion to the cold language of the abattoir report. The 
external influences on Biberkopf, Hoffmann and Mieze are so pervasive from social and moral pressures to conform, the conflicting drives of envy and jealousy, and the Darwinistic struggles between male rivals - that agency, especially criminal agency, threatens to evaporate altogether.

Although more narrative space is devoted to the female victim's experience of violence, Döblin also allows his male villain to speak. In both Die beiden Freundinnen und ihr Giftmord and Berlin Alexanderplatz, Döblin deploys various literary devices that allow him to express empathy, in particular, but not only, for his female characters: for the female poisoner in the former and the female victim in the latter. Little narrative space is devoted to the male victim of murder in Die beiden Freundinnen und ihr Giftmord, who, it can be safely assumed, deserves his fate. Here Döblin's aesthetics of empathy seek to understand the criminal act from the perspective of the female perpetrator, and are only partially offset by a poetics of shock, designed to evince some horror at least at the circumstances of the murder. Arguably Döblin's densely woven epic montage in Berlin Alexanderplatz is far more shocking on many scores. It tells of the murder of Mieze almost at once from all sides, from outside looking in and inside looking out. The plaintive voice of the victim makes it less detached, unleashing more emotional and pathos-laden registers; the insistent repetition of biblical quotes ('there is a time for everything') underscores the terrible inexorability of the young woman's murder.

In the murder scene and elsewhere in the novel, structural violence, or the "war of daily life', finds its expression in a type of linguistic and narrative violence inflicted upon the literary text. ${ }^{92}$ Syntax is disrupted, narrative linearity is fragmented, there is no single subjective perspective, as the point of view shifts back and forth from victim to villain, from outside to inside, from human to animal. Violence and the language of war are all-pervasive, and yet in Berlin Alexanderplatz the question of individual guilt and agency is less acute than the problem of the psychopathology of an urban population under siege from multiple quarters.

Overall, Döblin's deep familiarity with medical and psychiatric case writing traditions is less pronounced in Berlin Alexanderplatz. His medical training comes to the fore early in the novel in two main passages. The first is in the first chapter (or 'book'), when he inserts a passage from a medical textbook about the causes of sexual impotence: 'Sexual potency depends upon the combined action of (1) the internal secretory system, (2) the nervous system, and (3) the sexual apparatus'. ${ }^{93}$ The second occurs immediately after, when the narrator inserts a description of a contemporary treatment: 'Testifortan, authorised patent No. 365695, sexual therapeutic agent approved by Sanitary Councillor Dr Magnus Hirschfeld and Dr Bernhard Schapiro, Institute of Sexual Science, Berlin'. ${ }^{44}$ Homosexuality is also not a major concern of the novel, although it does figure in the homoerotic relationship between Mieze and Eva and in the homosexually charged relationship that develops between Reinhold and Franz. The most significant influence from Döblin's medical practice and 
his long-standing engagement with psychoanalysis, however, can be found in the scene at the end of the novel when Biberkopf, who has become delusional after the murder of Mieze, is admitted to Berlin-Buch. In a scene in which the doctors deliberate over his diagnosis, Döblin manages to parody both Freudian interpretations of psychopathology and his own mentor Hoche's more physiological approach to mental illness in the physicians treating Biberkopf. ${ }^{95}$

More broadly, this accomplished work and his earlier criminal case study in Die beiden Freundinnen und ihr Giftmord are aesthetic responses to the enduring impact of the First World War on normative categories of gender and the proletarian classes, and both can be read as attempts to grapple with the legacies of a diseased and traumatised body politic after the First World War. ${ }^{96}$ In his first attempt at literary case writing, Döblin sought to integrate the workings, even the discourse, of the unconscious into his representation of violence - with little success. Through experimenting with literary techniques to elicit empathy in his readers, he tried to show how women could be driven to violence. With its disparate components, the first edition of Die beiden Freundinnen und ihr Giftmord was an especially fragmented literary case study that reflected in many ways the writer's failure to integrate deep psychology with documentary realism. In the 1920s, Döblin was increasingly involved in the activities of the Berlin Psychoanalytic Institute, which emphasised healing the collective unconscious; consequently, his eyes were opened to the implications of cases of violent crime for the collective psyche of the masses. The Institute was the point of departure for many pioneers of political psychology who strove to incorporate Marxist philosophy and social theory into psychoanalysis. ${ }^{97}$ Although he never turned his back on Freudian psychoanalysis, like fellow members of the Berlin Psychoanalytic Institute, by the end of the 1920s Döblin increasingly questioned why Freud was not more concerned with the societal dimensions of his fragile, isolated ego. ${ }^{98}$ Berlin Alexanderplatz thus reflects many of the new concerns of socially aware Berlin psychoanalysts in Döblin's exploration of the wider socio-political dimensions of violence, its toll on relations between the sexes, and the social cost of war on public health.

Ultimately, however, Döblin was unable to explain the 'how' and 'why' of the specific cases of violent crime that are the focus of his literary treatments. He increasingly preferred narrative chaos or disorder over order, and multiple causal principles over single causes, and he privileged an almost impossibly complex amalgam of historical, social and physiological determinants of violence. Nevertheless, in the later work he found a language capable of convincingly representing the anonymous, impersonal violence that haunted German society in the years of the Weimar Republic, writing a fitting monument to the city of Berlin. Berlin Alexanderplatz is thus testament to his vast reservoir of experience 'as a doctor and a writer' acquired from treating patients from criminal and petty bourgeois milieu for an array of different medical, sexological and psychological conditions. 
Berlin Alexanderplatz cemented Döblin's reputation in Germany as a major novelist and in 1931, shortly after its publication, he was elected into the senate of the literary section of the Prussian Academy. ${ }^{99}$ Despite the critical acclaim he achieved through the novel, this was not sufficient for him to be able to give up practising medicine altogether, even though he did close his social welfare practice on the Frankfurter Allee and opened up a private practice in Charlottenburg in 1931. Döblin describes this move away from the poorer districts of Berlin as a 'catastrophic decision' ('katastrophalen Entschlu 8 '). ${ }^{100}$ It proved to be a crucial turning-point in his life: giving up his licence to work as a social welfare doctor effectively meant he would never practise medicine again. ${ }^{101}$ This downturn in his career was, however, soon to pale into insignificance when the National Socialists came to power in 1933 and Döblin found himself blacklisted.

In 1933 Döblin fled to France with six members of his immediate family. After the events of Kristallnacht he wrote: 'everything in Germany had become unbearable, not only politically but intellectually as well'. ${ }^{102}$ Initially, he had high hopes that exile would somehow reinvigorate his stagnating career. In France he became close friends with the critic and German scholar Robert Minder, who promoted his work, and Döblin and his family took out French citizenship. In 1940, after his two sons Wolfgang and Klaus were deployed with the French army, Döblin, his wife and youngest son escaped Europe for the USA, joining the community of German exiles in Los Angeles. Without a regular income from his medical practice, and unable to live from his writing, however, Döblin and his family found themselves in dire financial straits. After his contract as a story writer with MGM film studios expired Döblin was almost entirely at the mercy of the generosity of other émigrés, such as Lion Feuchtwanger. Unlike Thomas Mann, who lived a life of relative affluence in exile, Döblin struggled with his loss of relevancy and social status, his precarious financial situation and his grim lack of career prospects. He continued writing on a number of projects, among which was a four-volume epic about revolution, November 1918, which he finished in 1941. It was during this time that he converted to Catholicism in a futile attempt to establish himself in America. It was to make little difference, as he was later to write, and he had to 'live like a beggar for years'. He "was not only condemned to complete silence, disempowered, but even worse than that: degraded, worth less than a native illiterate person who can at least converse with his neighbours'. ${ }^{103}$ Those émigrés who were reliant on their language for their livelihood suffered especially, he writes, becoming little more than 'a living corpse'. ${ }^{104}$ Oddly, Döblin does not appear to have sought refuge in the émigré psychoanalytic community, for instance in the company of his mentor and fellow Jew and socialist Simmel. Simmel was also living in Hollywood during the war, where he helped to establish psychoanalytic institutes in Los Angeles and San Francisco. ${ }^{105}$ 
After the war, Döblin returned to Germany with his wife but found the post-war climate singularly unconducive to rebuilding his literary career. He had by now several finished manuscripts but he found it difficult to find a publisher for them. He finished his last novel, Hamlet oder die lange Nacht nimmt ein Ende (Hamlet, or Tales of a Long Night) in 1947 but he had little success in convincing one of the major publishers, Piper in Munich and Kiepenheuer in Cologne, to publish it. It was only towards the end of his life that, through the stewardship of poet Peter Huchel, he secured an East German publisher for his last work.

These difficulties were compounded by personal problems. At the war's end, Döblin and his wife learned of their son Wolfgang's suicide in 1940, when, as a member of the French armed services, he found himself confronted by German troops. Moreover, Döblin's health problems which had begun during the war continued; in 1949 he was diagnosed with Parkinson's disease, and in 1952 he suffered a further heart attack. Finally, feeling spurned and misunderstood, Döblin decided to leave Germany in 1953 and to resettle in France, where he lived until his death in 1957. He complained in a letter to Huchel in 1954: 'So the reading public does not want to buy anything of mine because I am an emigrant, and in addition to that, someone who served for France'. ${ }^{106}$

When compared with other celebrated modernist writers of the period, such as Franz Kafka, Mann, Joyce and Brecht, Döblin is today far less well known outside the German-speaking world. Even his last work failed to strike a chord with post-war publishers. Hamlet took up all the major themes of his earlier novels - the search for self; war; violence; the relationship between the sexes - in an account of an English soldier's peacetime struggles to come to grips with war trauma. In the conservative climate of the post-war period, when international publishers preferred Kafka, Mann and Rilke to more risky and difficult contemporary authors, Döblin, the assimilated Jew who had taken out French citizenship and spent the war in exile, reached an impasse. ${ }^{107}$ Cold War politics would also play their part in the lack of interest in Döblin's works: he found more political allies in the German Democratic Republic, but aesthetically he had more in common with West German writers such as Gottfried Benn. Had his health been better, and had he been willing to embrace the socialist experiment in East Germany, Döblin might have obtained a better chance of thriving, by emigrating there.

Döblin's empathetic literary case studies, which combined medical, sexological and social knowledge about human frailty, which he saw epitomised in the acts of criminals, were a masterful synthesis of real-life sources and new forms of expert knowledge. Yet, at least for the time being, the psychoanalytic case study about the low-life criminal failed to appeal as a form that the post-war era was ready to embrace. In West Germany the public was keen to discover new voices and to disavow most continuities with the past. Attention became focused on Gruppe 47, the literary association founded in 1947 that provided a prominent forum for 
emerging writers to present their experiments with politics and aesthetics. Then again, as one chapter of case writing in literature was closing, a new chapter in the history of the case study was opening: European psychoanalysts fleeing the ravages of German National Socialism and World War Two had exported the genre across the Atlantic Ocean, bringing it to unforeseen discursive contexts and tasks.

\section{Notes}

1 Richard Daniel Lehan, Realism and Naturalism: The Novel in an Age of Transition (Madison: University of Wisconsin Press, 2005), p. 5.

2 On his own admission, Döblin published 'a handful of publications' on medical topics early in his career. See Alfred Döblin, 'Autobiographische Skizze', in Schriften zu Leben und Werk, ed. Erich Kleinschmidt (Olten: Walter-Verlag, 1986), pp. $36-7$, p. 36.

3 Andreas Killen, Berlin Electropolis: Shock, Nerves, and German Modernity (Berkeley: University of California Press, 2006), pp. 1-2.

4 Killen, Berlin Electropolis, p. 2.

5 See Janet Beizer, 'Emma's Daughter: Femininity, Maternity, and "Mothersickness" in Madame Bovary", in Suzanne Nash (ed.), Home and Its Dislocations in Nineteenth-Century France (Albany: New York Press, 1993), pp. 265-83, p. 266.

6 Roland Dollinger, Wulf Köpke and Heidi Thomann Tewarson (eds), 'Introduction', in A Companion to the Works of Alfred Döblin (Rochester: Camden House, 2003), p. 1.

7 See Dollinger, Köpke and Thomann Tewarson, 'Introduction', p. 3.

8 Thomas Mann, 'Letter to Karl Bohm, September 27, 1925', in Letters of Thomas Mann 1889-1955, selected and trans. Richard and Clara Winston (Berkeley: University of California Press, 1970), p. 133.

9 See Wulf Köpke, The Critical Reception of Alfred Döblin's Major Novels (Rochester: Camden House, 2003), p. 96.

10 See Dollinger, Köpke and Thomann Tewarson, 'Introduction', pp. 5-7.

11 See Döblin's complaint in a letter to Hermann Kesten that none among the émigrés in California 'was laughing', except Stefan Zweig and Thomas Mann. Döblin, 'Letter to Hermann Kesten, 30th January 1942', in Briefe II, ed. Helmut F. Pfanner (Dusseldorf: Walter-Verlag, 2001), p. 159.

12 Georg Lukács, The Historical Novel, trans. Hannah Mitchell and Stanley Mitchell (London: Merlin, 1978).

13 Döblin, 'Der Geist des naturalistischen Zeitalters', in Schriften zu Ästhetik, Poetik und Literatur, ed. Erich Kleinschmidt (Olten: Walter-Verlag, 1989), pp. 168-90, p. 171.

14 Stéphane Michaud, 'L'exception allemande, ou quelques questions au naturalisme européen', Revue histoire de la littéraire de la France, 103:3 (2003), pp. 591-6, p. 596.

15 Richard Heinrich, 'Hermann Bahr und der Expressionismus', in Jeanne Benay and Alfred Pfabigan (eds), Hermann Bahr: Für eine andere Moderne (Bern: Peter Lang, 2004), pp. 175-88, p. 185. Michaud, 'L'exception allemande', p. 596.

16 Lehan, Realism and Naturalism, p. xvi.

17 Lehan, Realism and Naturalism, p. 3.

18 Irene Gammel, Sexualizing Power in Naturalism: Theodor Dreiser and Frederick Philip Grove (Calgary: University of Calgary Press, 1994), p. 23.

19 See Köpke, The Critical Reception of Alfred Döblin's Major Novels, p. 92.

20 The edition used herein is Alfred Döblin, Die beiden Freundinnen und ihr Giftmord (Dusseldorf: Artemis \& Winkler, 2001). 
21 See Russell A. Berman, The Rise of the Modern German Novel: Crisis and Charisma (Cambridge: Harvard University Press, 1986).

22 See Dollinger, Köpke and Thomann Tewarson, 'Introduction', p. 6.

23 'Medizin und Wissenschaft fesselten mich außerordentlich.' Döblin, 'Autobiographische Skizze', p. 36.

24 'Dem Kampf um das sogenannte Dasein.’ Döblin, 'Autobiographische Skizze', p. 25.

25 Döblin, 'Autobiographische Skizze', p. 25.

26 'Das Dunkle, das um diese Kranken war, wollte ich lichten helfen.' Döblin, 'Autobiographische Skizze', p. 25.

27 'Man mußte hinein in das Leibliche, aber nicht in die Gehirne, vielleicht in die Drüsen, den Stoffwechsel.' Döblin, 'Merkwürdiger Lebenslauf eines Autors', in Autobiographische Schriften und letzte Aufzeichnungen, ed. Edgar Pässler (Olten: Walter-Verlag, 1980), pp. 23-9, p. 25.

28 Veronika Fuechtner, Berlin Psychoanalytic: Psychoanalysis and Culture in Weimar Republic Germany (Berkeley: University of California Press, 2011), p. 9.

29 Fuechtner, Berlin Psychoanalytic, pp. 8-9.

30 '[M]ir persönlich hat Freud nichts Wunderbares gebracht.' Döblin, ‘Merkwürdiger Lebenslauf eines Autors', p. 25.

31 See Fuechtner, Berlin Psychoanalytic, p. 12.

32 'G]roße sensible Aufnahmebereitschaft, unerhörte Fähigkeit analytischen Eindringens, namentlich in der Richtung des Seelisch-Unbewußten.' Döblin, 'Erster Rückblick', in Autobiographische Schriften, pp. 37-94, p. 62.

33 Veronika Fuechtner, “Arzt und Dichter": Döblin's Medical, Psychiatric, and Psychoanalytical Work', in Dollinger, Koepke and Thomann Tewarson (eds), A Companion to the Works of Alfred Döblin, pp. 111-39, pp. 119-20.

34 See Christoph Hoffmann, 'Literaturforschung. Über medizinische Schriften Gottfried Benns', in Bernhard J. Dotzler and Sigrid Weigel (eds), 'fülle der combination': Literaturforschung und Wissenschaftsgeschichte (Munich: Wilhelm Fink, 2005), pp. 319-42.

35 Hoffmann, 'Literaturforschung', p. 320.

36 ' $[\mathrm{I}]$ st mir völlig fremd und auch total gleichgültig.' Quoted in Alfred Döblin, 'Der Nervenarzt Döblin über den Dichter Döblin', in Autobiographische Schriften, pp. $33-4$, p. 33.

37 Döblin, 'Der Dichter Döblin über den Nervenarzt Döblin', in Autobiographische Schriften, pp. 34-5, p. 34 .

38 'Ich habe allerlei Defekte, wahrscheinlich Komplexe, und der Routinier da roch wohl so etwas.' Quoted in Döblin, 'Der Dichter Döblin über den Nervenarzt Döblin', p. 34.

39 Döblin, 'Ökonomisches aus der Literatur', in Schriften zu Leben und Werk, pp. $77-9$, pp. 77-8.

40 'Es war eine schlimme Ehe.' Döblin, 'Erster Rückblick', in Autobiographische Schriften, p. 56.

41 Bettina Wahrig, 'Erzählte Vergiftungen: Kriminalitätsdiskurs und Staatsarzneikunde 1750-1850', in Gisela Engel, Susanne Scholz and Johannes Süßmann (eds), Fallstudien. Geschichte - Theorie - Methode (Berlin: Trafo, 2007), pp. 97-111, p. 98.

42 Hania Siebenpfeiffer, 'Böse Lust': Gewaltverbrechen in Diskursen der Weimarer Republik (Cologne: Böhlau, 2005), pp. 73-4.

43 Wolfgang Schäffner, Die Ordnung des Wahns: Zur Poetologie psychiatrischen Wissens bei Alfred Döblin (Munich: Wilhelm Fink, 1995), p. 8.

44 See Fuechtner, Berlin Psychoanalytic, pp. 188-9.

45 Döblin, 'An Romanautoren und ihre Kritiker?', in Schriften zu Ästhetik, Poetik und Literatur (Olten: Walter-Verlag, 1989), p. 123.

46 Joachim Linder, "Sie müssen das entschuldigen Herr Staatsanwalt, aber es ist 
so: Wir trauen Euch nicht...": Strafjustiz, Strafrechtsreform und Justizkritik im März, 1907-1911', in Jörg Schönert (ed.), Erzählte Kriminalität: Zur Typologie und Funktion von narrativen Darstellungen in Strafrechtspflege, Publizistik und Literatur (Tübingen: Niemeyer, 1991), pp. 533-70, p. 534.

47 Linder, 'Sie müssen das entschuldigen Herr Staatsanwalt, aber es ist so', p. 535.

48 André Jolles, Einfache Formen. Legende, Sage, Mythe, Rätsel, Spruch, Kasus, Memorabile, Märchen, Witz (Tübingen: Max Niemeyer, 1968), pp. 178-9.

49 Jolles, Einfache Formen, p. 191.

50 Johannes Süßmann, 'Einleitung: Perspektiven der Fallstudienforschung', in Engel, Scholz and Süßmann (eds), Fallstudien, pp. 7-27, 20.

51 Medical case writing produced reports that could be used either to illustrate medical theories or to show how medical knowledge should be applied to specific cases. Modern medicine, which has a long tradition of using case reporting of different kinds, has a similar relationship between the specific and the general. See Michael Stolberg, 'Formen und Funktionen medizinischer Fallberichte in der Frühen Neuzeit (1500-1800)', in Engel, Scholz and Süßmann (eds), Fallstudien, pp. 81-95.

52 Reports appeared in the morning and evening editions of Berliner Lokalanzeiger, Berliner Tageblatt, Deutsche Allgemeine Zeitung, the liberal Vossische Zeitung and the communist-aligned Vorwärts.

53 Siebenpfeiffer, 'Böse Lust', p. 105.

54 '[E]ntmenschte Frauen ... die sich ihrer Männer, die ihnen bei ihrer anormalen Beziehung zueinander unbequem waren ... mit Gift skrupellos und kalter Berechnung entledigen wollten.' Quoted in Siebenpfeiffer, 'Böse Lust', p. 107.

55 Siebenfeiffer, 'Böse Lust', p. 122.

56 My argument here is similar to that advanced by Hania Siebenpfeiffer, who argues that the sections of the work be understood not as a text-para-textual relationship but as individual components of a narrative whole which comment upon and complement one another in their truth claims. Siebenpfeiffer, 'Böse Lust', p. 132.

57 Siebenpfeiffer, 'Böse Lust', p. 122.

58 Katie Sutton, 'Sexual Pathologies and the Violence of War: Sexological and Psychoanalytic Responses to World War I', Limbus: Australian Yearbook of German Literary and Cultural Studies, 7 (2014), pp. 197-218, p. 202.

59 Elli's infantile sexuality and her homosexuality beg to be read in conjunction with a famous psychoanalytic text that also appeared in 1924, namely Sigmund Freud's essay 'The Dissolution of the Oedipus Complex'. See Sigmund Freud, The Standard Edition of the Complete Psychological Works by Sigmund Freud, ed. James Strachey, with Anna Freud, Alix Strachey and Alan Tyson, vol. XIX (London: Hogarth Press and Institute for Psychoanalysis, 1961), pp. 173-82.

60 'War leicht und lebenslustig.' Döblin, Die beiden Freundinnen, p. 5. (Unless otherwise noted, all translations into English from the novella are by Alison Lewis.)

61 Döblin, Die beiden Freundinnen, p. 17.

62 Döblin, Die beiden Freundinnen, p. 7.

63 '[E]inen alten Mechanismus, der erledigt war.' Döblin, Die beiden Freundinnen, p. 37.

64 Todd Herzog, 'Crime Stories: Criminal, Society, and the Modernist Case History', Representations, 80:1 (2002), pp. 34-61, p. 51.

65 "Überblicke ich das Ganze, so ist es wie in der Erzählung: "da kam der wind und riß den Baum um." Ich weiß nicht, was das für ein Wind war und woher er kam. Das Ganze ist ein Teppich, der aus vielen einzelnen Fetzen besteht, aus Tuch, Seide, auch Metallstücke, Lehmmassen dabei. Gestopft ist er aus Stroh, Draht, Zwirn. An manchen Stellen liegen die Teile lose nebeneinander. Manche Bruchstücke sind mit Leim oder Glas verbunden. Dennoch ist alles lückenlos und 
trägt den Stempel der Wahrheit. Es hat so sich ereignet; auch die Akteure glauben es. Aber es hat sich auch nicht so ereignet.' Döblin, Die beiden Freundinnen, p. 79.

66 'Er ist mir einfach zu schwer, man darf von abgearbeiteten Leuten nicht verlangen, sich durch so etwas freiwillig durchzuarbeiten.' Döblin, 'Der Nervenarzt Döblin über den Dichter Döblin', in Autobiographische Schriften, p. 33.

67 Berhard J. Dotzler, 'Wissen in Geschichten. Zur wechselseitigen Erhellung von Literatur, Medien und Wissenschaft', Berichte zur Wissenschaftsgeschichte, 32:4 (2009), pp. 319-28, p. 319.

68 Gammel, Sexualizing Power in Naturalism, p. 11.

69 Rita Felski, Uses of Literature (Malden: Blackwell, 2008), p. 95.

70 Döblin does quote from one letter, in which Ella Klein/Elli Link expresses her exasperation that her husband seems to be resisting the poison: "Wenn das Schwein doch nur bald krepierte. Das Schwein ist ja so zähe. Heute habe ich ihm Tropfen gegeben, aber ordentlich'. Döblin, Die beiden Freundinnen, p. 45.

71 'Sie war von ihrem Schicksal angegriffen wie ihr Mann. Sie war selbst in Lebensgefahr.' Döblin, Die beiden Freundinnen, pp. 40-1.

72 Joe Bray, 'The Effects of Free Indirect Discourse: Empathy Revisited', in Marina Lambrou and Peter Stockwell (eds), Contemporary Stylistics (New York: Continuum, 2007), pp. 56-67, p. 56.

73 Jürgen Link describes this dialectic between specialisation and reintegration of specialist discourses. Jürgen Link, 'Literaturanalyse als Interdiskursanalyse', in Jürgen Fohrmann and Harro Müller (eds), Diskurstheorien und Literaturwissenschaft (Frankfurt am Main: Suhrkamp, 1988), pp. 284-307, p. 285.

74 Ruth Koch, 'Der Kasus und A. Jolles' Theorie von den "Einfachen Formen", Fabula, 14:3 (1973), pp. 194-204, p. 196.

75 Fuechtner, Berlin Psychoanalytic, p. 40.

76 See Gabriele Sander, 'Döblin's Berlin: The Story of Franz Biberkopf', in Dollinger, Koepke and Thomann Tewarson (eds), A Companion to the Works of Alfred Döblin, pp. 141-60, p. 143.

77 See Sander, 'Döblin's Berlin: The Story of Franz Biberkopf', p. 145.

78 Fuechtner, Berlin Psychoanalytic, p. 40.

79 Maria Tatar, Lustmord: Sexual Murder in Weimar Germany (Princeton: Princeton University Press, 1995), p. 135.

80 Walter Benjamin, 'The Crisis of the Novel' [1930], in Michael W. Jennings, Howard Eiland and Gary Smith (eds), Walter Benjamin, Selected Writings, vol. II: 1927-1934 (Cambridge: Belknap Press, 1999), pp. 299-304, 301.

81 '[E]r benutzt sie für seine notorischen Nichtfakta.' Döblin, 'Der Bau des epischen Werkes', in Aufsätze zur Literatur, ed. Walter Muschg (Olten: Walter-Verlag, 1963), pp. 103-32, p. 109.

82 'starke Grundsituationen, Elementarsituationen des menschlichen Daseins.' Döblin, 'Der Bau des epischen Werkes', p. 107.

83 Döblin, 'Der Bau des epischen Werkes', p. 114.

84 Devin Fore, 'Döblin's Epic: Sense, Document, and the Verbal World Picture', New German Critique, 99 (2006), pp. 171-207, p. 187.

85 See Sander, 'Döblin's Berlin: The Story of Franz Biberkopf', p. 147.

86 Fore, 'Döblin's Epic', pp. 198, 177.

87 Sander, 'Döblin's Berlin: The Story of Franz Biberkopf', p. 143.

88 David B. Dollmayer, The Berlin Novels of Alfred Döblin (Berkeley: University of California Press, 1988), p. 71.

89 Alfred Döblin, Berlin Alexanderplatz: The Story of Franz Biberkopf, trans. Eugene Jolas (London: Secker \& Warburg, 1974), p. 409. 'Wir sind am Ende dieser Geschichte. Sie ist lang geworden, aber sie mußte sich dehnen und immer mehr dehnen, bis sie jenen Höhepunkt erreichte, den Umschlagspunkt, von dem erst Licht auf das Ganze fällt.... Es war ein Enthüllungsprozess besonderer Art. Franz Biberkopf ging nicht die Straße wie wir. Er rannte drauf los, diese 
dunkle Straße...' Alfred Döblin, Berlin Alexanderplatz: Die Geschichte vom Franz Biberkopf (Munich: DTV, 1965), p. 409.

90 Gammel, Sexualizing Power in Naturalism, p. 25.

91 Gammel, Sexualizing Power in Naturalism, p. 20.

92 Fuechtner, Berlin Psychoanalytic, p. 41.

93 Döblin, Berlin Alexanderplatz: The Story of Franz Biberkopf, p. 28. 'Die sexuelle Potenz kommt zustande durch das Zusammenwirken 1. Des innersektorischen Systems, 2. Des Nervensystems und 3. Des Geschlechtsapparates.' Döblin, Berlin Alexanderplatz: Die Geschichte vom Franz Biberkopf, p. 27.

94 Döblin, Berlin Alexanderplatz: The Story of Franz Biberkopf, pp. 29-30. 'Testifortan, geschütztes Warenzeichen Nr. 365695, Sexualtherapeutikum nach Sanitätsrat Dr. Magnus Hirschfeld und Dr. Bernhard Schapiro, Institut für Sexualwissenschaft, Berlin.' Döblin, Berlin Alexanderplatz: Die Geschichte vom Franz Biberkopf, p. 29.

95 See Peter Jelavich, Berlin Alexanderplatz: Radio, Film, and the Death of Weimar Culture (Berkeley: University of California Press, 2006), p. 17.

96 Fuechtner, 'Arzt und Dichter', p. 128.

97 See Fuechtner, 'Arzt und Dichter', p. 127.

98 See Fuechtner, 'Arzt und Dichter', p. 127.

99 Döblin, 'Erfolg', in Schriften zu Leben und Werk, p. 220.

100 Döblin, 'Erfolg', in Schriften zu Leben und Werk, p. 221.

101 Fuechtner, 'Arzt und Dichter', p. 129.

102 '[E]s war alles, nicht nur politisch, auch geistig unerträglich in Deutschland geworden.' Döblin, 'Abschied und Wiederkehr', in Schriften zu Leben und Werk, pp. 265-72, p. 267.

103 '[W]ar nicht nur zur völligen Stummheit verurteilt, entmündigt, sondern noch mehr: degradiert, weniger als sein Analphabet des Landes, der sich wenigstens mit seinen Nachbarn unterhalten kann.' Döblin, 'Abschied und Wiederkehr', in Schriften zu Leben und Werk, p. 270.

104 Döblin, 'Abschied und Wiederkehr', in Schriften zu Leben und Werk, p. 270.

105 See Fuechtner, Berlin Psychoanalytic, p. 187.

106 See Döblin, 'Letter to Peter Huchel, 30th September 1954', in Briefe II, p. 442.

107 See Döblin, 'Letter to Hermann Kesten, 7th May 1947', in Briefe II, pp. 253-4. 